\title{
Viticultural landscapes in transition: permanence and change
}

\section{Abstract}

This article concerns the transitions of cultural landscapes, especially of viticultural landscapes. The authors do not aim to present new definition of the term "landscape" but base their study on the existing output of Polish and foreign scholars. The fact that cultural landscapes are in a constant state of flux is stressed, and periods of both development and regression are included. These phenomena are illustrated with reference to the transformations of Poland's viticultural landscapes, the cultural landscapes of the Palmeral de Elche, and the mouth of the Vistula, as well as the metamorphosis of the landscape of Alto Douro. These examples may be an apt illustration of F. Braudel's concept of "Iongue durée".

Keywords

Cultural landscape $\bullet$ viticultural landscape $\bullet$ evolution • "Iongue durée"

() University of Warsaw - Faculty of Geography and Regional Studies
Joanna Miętkiewska-Brynda,

Jerzy Makowski

Department of Political Geography and Regional Studies, Faculty of Geography and Regional Studies,

University of Warsaw, Poland

e-mail: jmietkie@uw.edu.pl

e-mail: jmakowsk@uw.edu.pl

Received: 4 April 2018

Accepted: 29 May 2018
Introduction

The following article illustrates the "longue durée" perspective and metamorphosis of landscapes through the examples of several cultural landscapes, with particular attention paid to viticultural landscapes. The aim here, however, is not to analyze contemporary changes in viticultural landscapes as a consequence of the pressures associated with globalization or international institutions (e.g., regulations defined by the Council of the European Union).

The term "landscape" can be variously defined. Some definitions denote the sort of countryside that geographers prefer for their study areas, namely, natural landscapes and various kinds of cultural landscapes; for example, viticultural landscapes, the various aspects of which, are observed and studied; these aspects can be typological and regional. U. Myga-Piatek (2001) has compiled a wide range of definitions for "landscape," but quite a few authors have already written about the many and varied ways of defining the word. The present authors see no need to define "landscape," "cultural landscape," or "viticultural landscape," because they accept certain basic determinations (or "boundary conditions") that are expressed by the many definitions and characteristics found in the rich literature on landscape studies.

The objective existence of landscapes is predicated on these conditions. U. Myga-Piatek (2014), F. Plit (2014; 2016), A. Richling (2006), and others have written that landscapes are real entities; thereby alluding to the thoughts of A. Humboldt, R. Gradmann, F. Ratzel, and C. Ritter; and the ideas of C. Sauer (1925) and other Berkeley School geographers, as well as the Polish scholars, E. Romer, F.
Bujak (1920), and M. Dobrowolska (1948). ${ }^{1},{ }^{2},{ }^{3}$ These real entities, which exist materially, and, as it were, tangibly, and that are therefore independent of our will and sensory impressions, are definitely cultural landscapes (including viticultural landscapes) that have developed in geographical space.

The authors take it as given, as have F. Plit (2016) and many other scholars, that a particular landscape encompasses all the natural features and anthropogenic elements of the specified area. These constitute, indisputably, a viticultural landscape by virtue of their distinctive and inimitable features. The authors also share the view (Plit 2016, pp. 86-88) that we are dealing with natural landscapes when the topics of consideration, discussion, and research are "parts of the natural environment and the relationships that bind them to their surroundings," independently of any manmade changes, unless these have resulted in ecosystems being unable to regulate themselves. And, "if we restrict ourselves to [...] anthropogenic elements" and the "relationships that bind them to their surroundings," then we mean a cultural landscape (Plit 2016), which is "a landscape molded by humans as a result of civilizational development" (Myga-Piatek 2010). We consider the viticultural landscape to be one of the oldest of this type.

As previously stated, the term "landscape" is not defined in this paper. The authors are, however, aware of the regional

${ }^{1}$ See further Eberhardt, P. (2015), Müllerott, M. (1964), Rebok, S. (2003).

${ }^{2}$ See further Rybicka, E. (2014).

${ }^{3}$ See Kossowska-Cezak, U. (2011). 
diversification (even when only concerned with viticultural landscapes) that results both from the features of the natural environment (vineyards in the Crimea, Tuscany, La Mancha, the Douro Valley, and the Azores all have different landforms, soil bedrock, and climatic features) and the impact of anthropogenic factors. The typological feature common to all viticultural landscapes is the deliberate presence of grapevines within large and small vineyards. Vineyards regulate the landscape by filling it with harmony and making it familiar. They link up to form viticultural regions, that is, regions where the inhabitants rely on viticulture and winemaking for their livelihood. Various aspects of viticultural regions can be studied; for example, symbolic and aesthetic ones (Plit 2016). Moreover, as A. Humboldt said, they are "beautiful, scenic, majestic, etc." (Plit 2016). ${ }^{4}$ The diversity of viticultural landscapes has not gone unnoticed by UNESCO: 14 of the 102 cultural landscape entries on the organization's World Heritage List concern viticultural landscapes (UNESCO Committee, n.d.)

The constant evolution of landscapes and the longue durée

The fundamental process observed in any landscapes is one of constant change. This might even be considered the landscape's intrinsic feature (Pietrzak 2009; Myga-Piatek 2012; Wojciechowski 2010). An analysis of the drivers of these changes is a substantia research topic that occupies scholars in many countries. U. Myga-Piatek (2012), J. Plit (2016), F. Plit (2016), K. H. Wojciechowski (2010), and others make reference to cultural landscapes in Poland; while M. H. Mesquita Pina (2007), J. Piqueras (2014), M. del C. Cañizares Ruiz (2014), and A. Barros Cardoso (2015) are among those who refer to winery landscapes in Europe. Gradual, slow landscape changes, including cultural landscape changes, can be described as evolution, according to, for example, U. Myga-Piątek (2012), as they match the components of the definition of the term "evolution" in the WEP, viz. "tiny, continuous, gradual transformations (as opposed to 'revolution') (WEP 2002). However, discerning "successive changes proceeding in a specified direction," and especially "a developmental process of building up to ever more elaborate and variegated forms, to ever higher and increasingly perfected stages" (WEP 2002), would be somewhat inappropriate. The authors are in agreement with F. Plit (2016) here. This is not to say, however, that we exclude the possibility of such changes in cultural - and that includes viticultural - landscapes.

It is worth emphasizing that specific examples of cultural landscape regression (or recession), that is, reverting to previous developmental stages, are equally likely to be found during landscape transformation, in other words, the transformations need not be evolutionary. This can, for example, result from the depopulation of areas that were once exploited, and land being abandoned and left for nature to reclaim. This has often been observed by the authors - even in viticultural landscapes.

A. M. Aubreville (1949) describes northern African landscapes in states of deep recession, degraded to desertification and all but annihilated as cultural landscapes; as does J. Dorst (1987) for the Mediterranean Basin. Dorst further points out that deeply regressed (anthropogenic) landscapes have even been observed in antiquity. ${ }^{5}$

Environmental changes are one of the major causes of serious cultural landscape changes - even going so far as to annihilate them. ${ }^{6}$ These can be abrupt, for example, volcanic eruptions and earthquakes, or slow and gradual, as in the

\footnotetext{
${ }^{4}$ These definitions can be found in the works of Alexander Humboldt, e.g., Podróż po rzece Orinoko, trans. F. Mirandola. Available from: <https://wolnelektury.pl/katalog/ lektura/humboldt-podroz-po-rzece-orinoko.html>. [16 January 2018].

5"our land, compared with what it was, is like the skeleton of a body wasted by disease" wrote Plato, here cited by J. Dorst (1987).

${ }^{6}$ The term, in this sense, has been borrowed from M. Kistowski (2010).
}

example of climatic changes. The history of grapevine cultivation in Poland is worth mentioning in respect to the latter. Tradition, legislative conditions, commercial law, the trade situation, and fashion, as well as wars, the laws imposed by invaders, and even their culinary preferences, have to be factored into any list of drivers of landscape change (Myga-Piątek 2012; Miętkiewska-Brynda \& Makowski 2016). $\cdot{ }^{7,8}, 9$ The influx of new settlers, colonizers, and refugees, who bring new, or simply different, grapevine cultivars with them, can also impact change in a viticultural landscape. ${ }^{10}$

When cultural landscape changes are not caused by armed conflict, or triggered by drastic climatic change, and bear no trace of blights or pestilential plagues, then they occur rather "as a result of the natural evolution of the local culture (including voluntary adaptation to external inspirations), as well as the appearance of people from a different kind of culture in a particular area, which effect changes in political affiliation etc." (Plit 2016). ${ }^{11}$ This means that the new is imposed on the old, and alters and modifies it but does not eliminate it, even though there is a slice of history between them. This has led U. MygaPiatek (2012) to detect "a stratification of cultural landscapes," and F. Plit (2016) to discern "multilayeredness" and succession. For the present authors, this calls to mind the longue durée perspective and "landscape reversion" (Miętkiewska-Brynda \& Makowski 2016). The longue durée perspective of Braudel (Bobińska 1987; Braudel 1999) continues to inspire and be debated (González Martínez 2005; Pawłuszko 2017) . Palmeral de Elche, as recently described by one of the authors (Miętkiewska-Brynda 2014), serves as an excellent example of this perspective, and at the same time, as an example of the imposition of successive landscape layers. ${ }^{12}$

Elche existed in Roman times (from the 2nd century BCE to the 4th century CE). After the fall of the Roman Empire and a brief period of Visigoth rule, the Moorish domination of the Iberian Peninsula and Al-Andalus began in the 8th century. ${ }^{13}$ During the 8th and 9th centuries, the Muslims made an oasis out of the semi-arid Elche by digging a network of canals to irrigate the date palms they had planted along with the arable patches (huertas) between them. They thereby formed the landscape of Palmeral de Elche as it is known today. Subsequent conquerors and new landlords, whether out of respect and admiration for the engineering involved, or on account of its economic importance, did not make any significant changes to the composition of the palm grove. Palmeral de Elche, although slightly destroyed, survived the Napoleonic wars, the industrial revolution, and the Spanish Civil War. Despite the loss of its economic functionality, it remains the pride and emblem of Elche due to its symbolic importance. Palmeral de Elche was designated a UNESCO World Heritage Site in the cultural landscape category in 2000 , described "as an oasis - an agricultural production system on arid land and the sole example of Arab agricultural methodology on the European continent" (Polish UNESCO Committee).

One of the Polish landscapes that fits the notion of longue durée is that of Żuławy Wiślane, the Vistula river's delta. The landscape transformations in this region have been described by numerous authors, including Myga-Piątek (2012), J. Plit (2016), and B.

7U. Myga-Piątek talks of "landscape tradition" (2012)

${ }^{8}$ See further e.g., EU Council Regulation 1234/2007 from Oct. 27, 2007.

9 In Romania, hybrid cultivars were abandoned in favor of common grapevines (vitis vinifera) (Nedelcu 2014)

${ }^{10}$ The example of Hungary is illustrative (Bosak 2010 b)

${ }^{11}$ Called also: "ewolucją krajobrazu (zmianami ewolucyjnymi krajobrazu kulturowego)" (evolution of the landscape [evolutionary changes in the cultural landscape]) and "rozwojem krajobrazu kulturowego" (development of the cultural landscape) (MygaPiątek 2012)

${ }^{12} \mathrm{~A}$ palm grove in Elche, Alicante Province, Spain.

${ }^{13} \mathrm{Al}$-Andalus was the Arabic name of that part of the Iberian Peninsula under Islamic rule (711-1492). The name was given by the conquerors. 
Lipińska (2011). Settlers - from Germany in the 14th century, and the Netherlands in the 16 th to 18 th centuries, mostly Mennonites - gradually altered the landscape (Makowski 1993). It was initially shaped solely by water. These formerly swampy areas have always been prone to flooding. Over the centuries, they have been transformed by human activity to create a fertile agricultural region with a landscape seldom encountered in Poland. Specific features, for example, the rectangular field layout, roads, canals, and planted trees; have transformed the original landscape. The area, in which periodic flooding had limited human settlement and farming, has been transformed into arable and inhabitable land by means of a series of hydrotechnical measures. The constant effort (e.g., rebuilding levees destroyed by flooding or military activities, and restoring flooded farms and sand-covered fields) has reshaped the landscape and allowed it continue to exist in its new form. The most visible traces of the Mennonites' presence in the region are the residential architecture, prayer houses, Mennonite cemeteries, windmills, hydrotechnical structures, and trees - especially weeping willows (Woźniczko \& Jędrysiak 2013).

The history of many viticultural landscapes, in a similar way to the history of the Żuławy Wiślane, illustrates Braudel's conception of the longue durée (Wrzosek 1994). In Poland, viticultural landscapes were formed at the beginning of the second millennium. The Middle Ages was a warm period for Central Europe, including Poland (Bradley 2003); and this was conducive to settlement and farming, and no doubt also to the introduction and expansion of new plantations (e.g., fruit trees and grape vines) (Jones 2007). Christian monks contributed greatly to the agricultural innovation in this part of Europe by spreading new agricultural techniques and methods, promoting gardening, and developing animal husbandry (Strzelczyk 1992). They began working in Poland in the 10th century. Other religious orders arrived in the following centuries, and grapevine cultivation was spread as a result of their activities. ${ }^{14}$ This is attested to by numerous historical sources, such as, grants, papal bulls authorizing churches and monasteries to pay emoluments, deeds of purchase, sale and exchange (of vineyards), city and court registers, remuneration registers, survey documents, goods inventories, and the observations of travelers and historians regarding vineyards (Kwapieniowa 1959). ${ }^{15}$

At the turn of the 16th century, when vineyards in many regions of southern and central Poland were becoming a permanent fixture of the cultural landscape (although there was surely no comparison to the viticultural landscapes of Tuscany, Burgundy or Apulia), the climate started to become unfavorable. A long period of cooling followed the centuries of mildness and warmth. This persisted for the next 300 to 350 years (IPCC 2001) and is known as the Little Ice Age. This cooling had a considerable impact on agriculture all over Europe (Mannion 2001). In Central Europe, it brought about a fall in crop yields and a steady shrinking of the range over which certain crops could be cultivated (grapevines being among the crops affected).${ }^{16}$ Maintaining existing vineyards (let alone planting new ones) ceased to be profitable (Jones 2007); and while the shortfall in domestic wine in Poland could be (and was) supplemented by imports, the disappearance of vineyards was an irrevocable loss. The diversity of the cultural landscape declined.

As if severe winters and cool, rainy summers were not enough, the 17th century brought devastating wars that impoverished the cities that had comprised the major wine consumption markets.

\footnotetext{
${ }^{14} \mathrm{~J}$. Miętkiewska-Brynda and J. Makowski (2016) have recently made mention of this. ${ }^{15}$ The Arabian-Sicilian geographer Al-Idrisi, who wrote the oldest extant description of Kraków in the 12th century, mentions numerous vineyards amid the magnificence of the town (Lewicki 1945).

${ }^{16}$ "Vintages were better and more plentiful in former times", wrote Marcin Kromer in Polonia sive de situ, known as Opis Polski (A Description of Poland) c. 1557, cited here by M. Kwapieniowa (1959).
}

Only a handful of Polish vineyards survived the 18th century, and many of those that remained fell victim to phylloxera (Bosak, n.d.), which appeared in Europe in the middle of the 19th century and caused drastic changes in viticultural landscapes (i.e., the destruction of millions of hectares of vineyards). Such changes - both the destruction and the regeneration of viticultural landscapes - took place in many wine-producing regions across Europe, including in France, Spain, Italy, and Dalmatia (Bosak 2010)..$^{17}$

The landscape transformations in the Douro Valley are also well documented (Mesquita Pina 2007). Archaeological discoveries in the Douro Valley, for example, fossilized seeds, confirm that grapevines have long been cultivated here. There is also evidence that wine was produced there in Roman times (from the presence of large stone tanks known as lagares) (Brochado de Almeida 1996). Viticulture, however, was not the dominant culture within the agricultural landscape at that time, or for centuries afterwards; in fact, it was not developed on a large scale until the Middle Ages. It was mainly monks who cultivated grapevines and made wine. The general populace used this favorably situated land to grow cereals, raise nutritional crops, and breed animals; and if they tended grapevines, it was mainly for their own needs. Part of the land remained forested for hunting purposes, and any land near water was a malaria hazard. Through the efforts of the monks, the acreage devoted to viticulture systematically increased, wine production expanded, and wine quality improved from the middle of the second millennium. Rebello da Fonseca (cited in Lidell \& Price 1992) wrote in 1791 that there were no large farms (quintas) cultivating grapevines and producing wine, but 100 years later (in the time of the Marquês de Pombal), there were quite a number of vineyards occupying a considerable area. At the turn of the 20th century, however, phylloxera and mildew destroyed a lot of the vineyards, and, as previously mentioned, some of them disappeared from the landscape for good while many others were abandoned by their owners who had lost their livelihood, and were forced to leave the region and seek employment elsewhere. Some of the vineyards, founded on lighter soil, survived the plague, but the grape harvest was no more than a third of what it had been before the arrival of phylloxera.

\section{Regeneration of viticultural landscapes}

When talking about the degradation of cultural landscapes, the regeneration and positive changes that follow should also be borne in mind. In many places phylloxera turned out not to be as virulent as first thought. When vineyards were rebuilt, less propitious locations were avoided and inferior varieties of grape were eschewed; moreover, numerous research centers and wine schools were opened. These assisted vinedressers in selecting varieties and rootstocks, and taught new, more efficient methods of cultivating and protecting grapevines. Viticulture, which had changed little since Roman times, was revolutionized in the wake of the phylloxera scourge (Bosak 2010).

Once the phylloxera aphid had been combated, the Alto Douro landscape underwent further metamorphoses. Various forms of vineyard, which can consist of anything from 3,000 to 5,000-6,000 vines per hectare, currently exist side-by-side. They each have their own cultivation and harvesting techniques, and together comprise a landscape mosaic. The oldest form of vineyard consists of narrow terraces with, at most, two rows of vines supported by low loose-stone walls. These were built before the phylloxera disease outbreak. Some were abandoned (mortórios), and are now embedded in the landscape as fossils

\footnotetext{
${ }^{17}$ The phylloxera plague has been described (no doubt with exaggeration) as one of the most drastic periods in the history of European viticulture, and as comparable with the fall of the Roman Empire (Bosak 2010).
} 


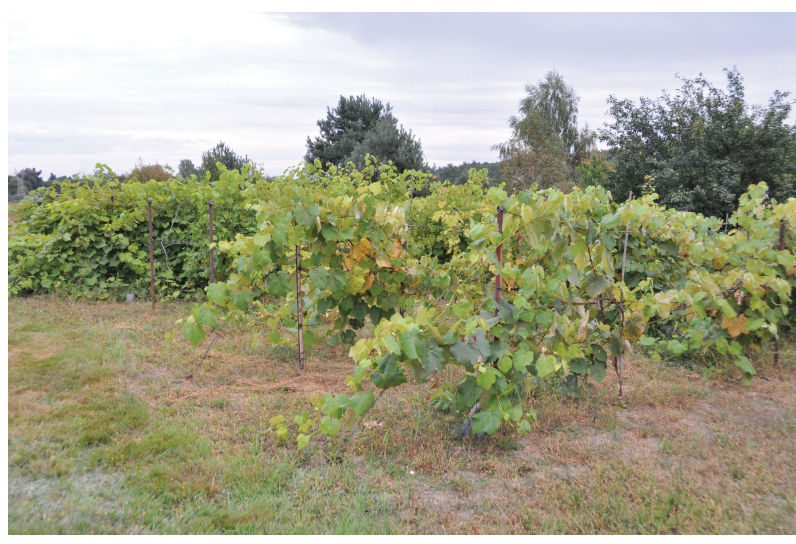

Figure 1. Some abandoned vineyards (mortórios) are now present in the landscape as fossils in the sediment (Photo: Authors)

in the sediment. There are also wide terraces of up to 10 rows of vines, typical of large farms. These are sloping and supported by solid walls, and are considerably more recent having been built after the main wave of phylloxera had passed. There are also vineyards along the sides of the valley and on its natural slopes (i.e., without terraces), with rows of vines running along the contour lines and across them along the slopes (vinhas ao alto). These were built independently (Instituto dos Vinhos do Porto, n.d., Guichard et al. 2013).

Cultural landscape changes can also be observed in Poland. In the case of viticultural landscapes, it is their return that is most evident. There are any number of places where vineyards have made a comeback after a lapse of centuries (although not always in the same location), examples being the vineyards planted around Kraków, Jasło, Zielona Góra, and Sandomierz. Poland now has nearly 400 vineyards, with a combined area of almost 450 ha; and some 70 of these sell their wine (Przybek 2018). Most of these vineyards, and most of the land they occupy, are recorded in the south and west of the country, that is, in regions where the vestiges of former vineyards are corroborated by historical sources.

\section{Final remarks}

All cultural landscapes, and therefore also viticultural landscapes, are in a state of continual transition. This means the slow change (which tends to be discerned in their evolution), as well as periods of stagnation, and even regression of some cultural landscapes. These changes only become noticeable after a long period of time, usually measured in years, as the appearance of something new superimposed on the old, and the new coexisting with the old without obliterating it. These

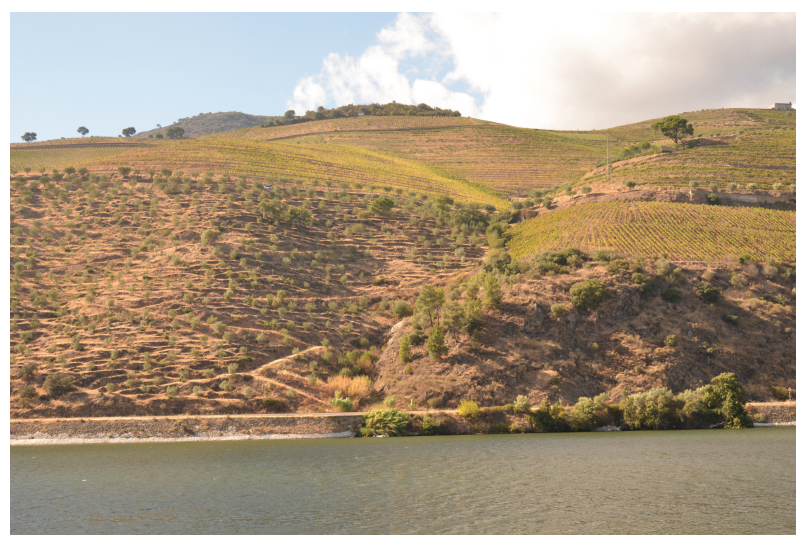

Figure 2. Young vineyards like Sandomierz (Małopolska Upland) have been established in the areas of once existing vine plantations (Photo: Authors)

transitions include periods of violent change; the rapid spread of new peoples, things, and ideas; or landscape degradation.

The characteristic feature of cultural (including viticultural) landscapes is their endurance in the face of change. Something always seems to remain whenever a cultural landscape is destroyed. It might be material vestiges that play the role of a landscape's canvass - comparable to the warp of an expensive fabric. It might also be simply a memory of what was, and what, under favorable conditions, could be again. All this ties in with the longue durée conception of F. Braudel (1999), as is evident in the existence (e.g., in the cultural landscape) of the "outlines of a deep structure" that is not easily destroyed (Braudel 1999). ${ }^{18}$ This endurance may stem from a cultural environment that typically stores the past (e.g., clearly visible cultivation terraces that have not been used for centuries), or a cultural environment that $U$. Myga-Piatek (2014) describes as being "shaped by the genius loci - the pervading spirit of the place" that knits "the space, the landscape, and the cultural environment into a cohesive triad" (Myga-Piatek 2014). A concealed nature (natural environment) resides in this triad.

If Myga-Piatek's (2014) contention that "a cultural environment familiarizes the landscapes (not just cultural, but also natural ones) and that it 'educates' the next generation in traditional (indigenous) manners and ways of behave [sic], and paradigms of shaping the landscape," is accepted, then it can also be assumed that the genius $l o c i^{19}$ allows for the revelation of an appropriate, and perhaps even the best, landscape vocation, whether that be vineyards or fields of grain.

${ }^{18}$ See further C. Bobińska 1987, W. Wrzosek, 1994

${ }^{19}$ See further Norberg-Schulz, Ch. 1980, Wilkoń, A., T. Sławek 2007 <http://www.winologia.pl/teksty_filoksera.htm>

from: <http://

Aubréville, AM 1949, Climats: forêts et désertification de l'Afrique tropicale, Société d'éditions géographiques, maritimes et coloniales, La Rose, Paris.

Barros Cardoso, A 2015, Douro. Vinho, História \& Património, Publicação anual No04, Associação Portuguesa de História da Vinha e do Vinho, Porto.

Bobińska, C 1987, 'Czas i przestrzeń Fernanda Braudela' ['The time and the space of Fernand Braudel'] Historyka. Studia Metodologiczne [Historics. Methodological Studies], vol. XVII, pp. 31-32.

Bosak, W 2010 a, 'Filoksera' ['Phylloxera'], Winologia. O winorośli $i$ winie [Wineology. On vines and wine]. Available

Bosak, W 2010 b, Narodziny wielkich win tokajskich [The birth of the great Tokaj wines]. Available from: <http://www. winologia.pl/teksty_tokaj.htm>. [17 January 2018].

Bosak, W n.d., Bardzo krótka historia uprawy winorośli w Polsce [A very short history of viticulture in Poland]. Available from: <www.collegiumvini.pl>. [18 December 2017].

Bradley, RS Hughes, MK Diaz, HF 2003, 'Climate Change in Medieval Times', Science, vol. 302, pp. 404-405.

Braudel, F 1999, Historia $i$ trwanie [History and duration], „Czytelnik” [“Czytelnik” Publishing House], Warszawa. 
Brochado de Almeida, CA 1996, 'O cultivo da Vinha durante Antiguidade Clássica na Região Demarcada do Douro. Ponto da situação', Douro-Estudios\&Documentos, vol. 1(2), pp. 18-30.

Bujak, F 1920, Historja osadnictwa ziem polskich w krótkim zarysie [A brief outline of the history of the settlement of Polish lands], Wydawnictwo Głównego Urzędu Ziemskiego Nr. 1 [Central Land Office Publishing House no. 1], Warszawa.

Cañizarez Ruiz, M. del C 2014, 'Paisajes culturales, ordenación del territorio y reflexciones desde la geografía en España', Polígonos, Revista de Geografía, no 26.

Council Regulation (EC) No 479/2008 of 29 April 2008 on the common organisation of the market in wine, amending Regulations (EC) No 1493/1999, (EC) No 1782/2003, (EC) No 1290/2005, (EC) No 3/2008 and repealing Regulations (EEC) No 2392/86 and (EC) No 1493/1999. Available from: <https://publications.europa.eu/pl/publicationdetail/-/publication/2cfd285f-7110-40a8-ac3e-fa27f5aefffc/ language-pl>. [18 January 2018].

Dobrowolska, M 1948, 'Dynamika krajobrazu kulturalnego' ['The dynamics of the cultural landscape'], Przegląd Geograficzny [Geographical Review], vol. 21, no. 3-4, pp. 152-203.

Dorst, J 1987, Siła życia [Life force], PIW [State Publishing Institute (PIW)], Warszawa.

Eberhardt, P 2015, 'Poglądy antropogeograficzne i geopolityczne Friedricha Ratzla'['The anthropogeographical and geopolitical views of Friedrich Ratzl'], Przegląd Geograficzny [Geographical Review], vol. 87, no. 2, pp. 199-224. Available from: <http://rcin.org.pl/Content/55414/WA51_74981_ r2015-t87-z2_Przeg-Geogr-Eberhard.pdf>. [18 December 2017].

González Martínez, J R 2005, Longue Duree processes and geohistorical conformation In Mexico. The case of fishermen communities of Lower Paploapan Basin (Veracruz, Mexico), Wydawnictwo Uniwersytetu Warszawskiego, Warszawa.

Guichard F, Martins Pereira G, Guimaraens D, Peixoto F, Ribeiro de Almeida A, da Silva Lopes T, Sandeman G \& Carvalho, M 2003, O Vinho do Porto, Instituto do Vinho do Porto, Porto.

Humboldt, A 1925, Podróż po rzece Orinoko [Journey on the Orinoco River]; opracowany na podstawie: Aleksander Humboldt, 1925, Podróż po rzece Orinoko, tłum. F. Mirandola, Instytut Wydawniczy „Zdrój”, Warszawa [developed on the basis of: Aleksander Humboldt, 1925, Journey on the Orinoco River, translated by F. Mirandola, "Zdrój" Publishing Institute, Warsaw]. Available from: <https://wolnelektury.pl/ katalog/lektura/humboldt-podroz-po-rzece-orinoko.html>. [16 January 2018].

Instituto dos Vinhos do Porto n.d., Cultivo de la Viña. Available from: <https://www.ivdp.pt/pagina.asp?idioma=3\&codPag $=$ $17 \& \operatorname{codSeccao}=4 \&>$ [22 January 2018].

IPCC: Climate Change 2001: Working Group I: The Scientific Basis 2.3.3 Was there a "Little Ice Age” and a „Medieval Warm Period"?. Available from: <https://www.ipcc.ch/ ipccreports/tar/wg1/070.htm>. [13 November 2015].

Jones, G 2007, 'Making Wine in a Changing Climate', Geotimes, 4 August. Available from: <http://www.geotimes.org/aug04/ feature_wineclime.html>. [14 December 2017].

Kistowski, M 2010, 'Eksterminacja krajobrazu Polski jako skutek wadliwej transformacji' ['Polish landscape extinction as the effect of faulty social-economical state transformation'], in Studia krajobrazowe a ginące krajobrazy [Landscape and disappearing landscape studies], eds D Chylińska \& J Łach, Zakład Geografii Regionalnej i Turystyki, Uniwersytet Wrocławski, Wrocław, pp. 9-20.
Kossowska-Cezak, U 2011, 'Eugeniusz Romer - w 140. rocznicę urodzin' ['Eugeniusz Romer - on his 140th birthday'], Przegląd Geofizyczny [Geophysical Review], vol. 56, no. 1-2, pp. 111-121.

Kwapieniowa, M 1959, 'Początki uprawy winorośli w Polsce' ['The beginnings of viticulture in Poland'], Archaeological Materials, [Materiały Archeologiczne], vol. 1, Muzeum Archeologiczne w Krakowie, Kraków, pp. 353-400.

Lewicki, T 1945, Polska i kraje sąsiednie w świetle Księgi Rogera geografa arabskiego z XII w. Al Idrisi'ego, [Poland and neighbouring countries in the light of the Tabula Rogeriana created by the 12th century Arab geographer Muhammad Al-Idrisi], vol. I, Polska Akademia Nauk. Komitet Orientalistyczny, PWN, Kraków

Lidell, A Price, J 1992, Port Wine Quintas of the Douro, Philip Wilson Publishers Ltd., London, United Kingdom.

Lipińska, B 2011, Ochrona i kształtowanie zabytkowego krajobrazu Żuław Wiślanych [Protection and shaping of the historic landscape of Żuławy Wiślane], Gdańsk.

Makowski, J 1993, Wały przeciwpowodziowe Dolnej Wisły, historyczne kształtowanie, obecny stan i zachowanie w czasie znacznych wezbrań [Lower Vistula anti-flood embankments, historical shaping, current condition and maintenance during major swells], Wydawnictwo IBW PAN, Gdańsk.

Mannion A, M 2001, Zmiany środowiska Ziemi [Changes in the Earth's environment], WN PWN, Warszawa.

Mesquita Pina, MH 2007, 'O Alto Douro. Um espaço contrastante em mutação', Temas Portugeses, vol. I-IV, Imprensa Nacional-Casa da Moeda, Lisbon.

Miętkiewska-Brynda, J 2014, 'El Palmeral - (długie) trwanie nadrzecznej oazy' ['El Palmeral - the (long) duration of the riverside oasis'], Czasopismo Geograficzne [Geographical Journal], vol. 85, no. 1-2, pp. 67-84.

Miętkiewska-Brynda, J \& Makowski, J 2016, 'Powracające krajobrazy' ['Returning landscapes'], Czasopismo Geograficzne [Geographical Journal], vol. 87, no.1, pp. 101-120.

Müllerott, M 1964, 'Gradmann, Robert Julius Wilhelm', Neue Deutsche Biographie (NDB), vol. 6, Duncker \& Humblot, Berlin, pp. 703-705. Available from: <https://www.deutschebiographie.de/gnd118696904.html\#ndbcontent>. December 2017].

Myga-Piątek, U 2001, 'Spór o pojęcie krajobrazu w geografii i dziedzinach pokrewnych' ['The dispute over the concept of landscape in geography and related fields'], Przegląd Geograficzny [Geographical Review], vol. 73, no. 1-2, pp. 163-176.

Myga-Piątek, U 2010, 'Przemiany krajobrazów kulturowych w świetle idei zrównoważonego rozwoju' ['Transformation of Cultural Landscapes in the Light of the Idea of Sustainable Development'], Problemy ekorozwoju [Problems of Sustainable Development], vol. 5, no 1, pp. 95-108.

Myga-Piątek, U 2012, Krajobraz kulturowy. Aspekty ewolucyjne $i$ typologiczne [Cultural landscape. Evolutionary and typological aspects], Uniwersytet Śląski, Katowice.

Myga-Piątek, U 2014, 'O wzajemnych relacjach przestrzeni i krajobrazu kulturowego. Rozważania wstępne' ['About mutual relations between space and cultural landscape. Preliminary considerations.'], Prace Komisji Krajobrazu Kulturowego [Works of the Cultural Landscape Commission], no. 24 , pp. 27-44.

Nedelcu, A 2014, 'Potential of wine turism in Romania. Case Study: Dealu Mare Vineyard', Annals of the "Constantin Brâncuşi” University of Târgu Jiu, Economy Series, 
Special Issue/2014- Information society and sustainable development, pp. 50-55. Available from: <http://www.utgjiu. ro/revista/ec/pdf/2014-04.Special/9_Nedelcu\%20Adrian. pdf>. [18 January 2018].

Norberg-Schulz, Ch 1980, Genius Loci, Towards a Phenomenology of Architecture, Rizzoli, New York.

Pawłuszko, T 2017, 'Analiza gospodarki świata według Fernanda Braudela' [Fernand Braudel's Approach to WorldEconomy Analysis], Teka Komisji Politologii i Stosunków Międzynarodowych, no. 12/2, pp. 125-146.

Pietrzak, M 2009, 'Aktualne i nieaktualne problemy ekologii krajobrazu' ['Current and out-of-date problems of landscape ecology'], Problemy ekologii krajobrazu [Problems of landscape ecology], vol. XXIII, pp. 11-18.

Piqueras, J 2014, Historia de la vida y el vino en España, Publicaciones de la Universitat de València.

Plit, F 2014, ,Krajobraz w przestrzeni czy przestrzeń w krajobrazie' ['Landscape in the space or space in landscape'], Prace Komisji Krajobrazu Kulturowego [Works of the Cultural Landscape Commission], no. 24, pp. 19-26.

Plit, F 2016, Krajobrazy kulturowe w geografii polskiej. Szkice. [Cultural landscapes in Polish geography. Sketches.], Warszawa, Wydawnictwo Akademickie Dialog.

Plit, J 2016, 'Krajobrazy kulturowe Polski i ich przemiany' ['Cultural landscapes of Poland and their evolution'], Prace Geograficzne IGiPZ PAN [Geographical Works of the Institute of Geography and Spatial Organization PAS (IGiPZ PAN)], no. 253, Warszawa.

Polish UNESCO Committee n.d. Available from: <http://www. unesco.pl/polski-komitet-ds-unesco/>. [18 December 2017].

Przybek, P 2018, 'Mapa 399 polskich winnic' ['Map of 399 Polish vineyards'] [online], Kraków: WinOgrodnicy.pl, Available from: <http://winogrodnicy.pl> [26 January 2018].

Rebok, S 2003, 'La expedición americana de Alexander von Humboldt y su contribución a la ciencia del siglo XIX', Bulletin de l'Institut français d'études andines, vol. 32 (3) pp. 441-458. Available from: <http://journals.openedition.rg/ bifea/6080>. [18 December 2017].

Richling, A 2006, 'Czy istnieja krajobrazy naturalne i kulturowe' ['Do the natural and cultural landscapes exist?'], Problemy ekologii krajobrazu [Problems of landscape ecology], vol. 18, pp. 119-122.
Rybicka, E 2014, Geopoetyka. Przestrzeń i miejsce we współczesnych teoriach i praktykach literackich [Geopoetry. Space and place in modern literary theories and practices], Wydawnictwo Universitas, Kraków.

Sauer, CO 1925, 'La morfología del paisaje', University of California Publications in Geography. vol. 2, no. 2, pp. 19-53. Traducción de Guillermo Castro H.

Strzelczyk, J (ed.) 1992, Cystersi w kulturze średniowiecznej Europy [Cistercians in the medieval culture of Europe] Wydawnictwo Naukowe UAM, Poznań.

UNESCO Committee n.d., Cultural Landscapes. Available from: <http://whc.unesco.org/en/culturallandscape/>. [28 December 2017].

WEP, vol. 8, 2002, Wydawnictwo Naukowe PWN [Polish Scientific Publishers (PWN)], Warszawa.

Wilkoń, A \& Sławek, T (ed.) 2007, 'Genius Loci w kulturze europejskiej: Kampania i Neapol. Szkice komparatystyczne' ['Genius Loci in European culture: Campania and Naples. Comparative Sketches'], Prace Naukowe Wydawnictwa Uniwersytetu Śląskiego w Katowicach, no. 2522.

Wojciechowski, KH 2010, 'Wartości i walory krajobrazów przemijających i efemerycznych' ['The values and qualities of fleeting and ephemeral landscapes'], in Studia krajobrazowe a ginące krajobrazy [Landscape and disappearing landscape studies], eds D Chylińska \& J Łach, Zakład Geografii Regionalnej i Turystyki. Uniwersytet Wrocławski, Wrocław, pp. 37-43.

Woźniczko, M \& Jędrysiak, T 2013, 'Miejsca spotkań zapomnianego dziedzictwa kulturowego menonitów na ziemiach polskich' ['Meeting places for the forgotten cultural heritage of Mennonites in Poland'] in Kultura i turystykamiejsca spotkań [Culture and tourism - meeting places], eds B Krakowiak, A Stasiak \& B Włodarczyk, Łódź, pp. 395-416.

Wrzosek, W 1994, ,Idea kultury materialnej F. Braudela' ['The idea of F. Braudel's material culture'], Kwartalnik Historii Kultury Materialnej [History of Material Culture Quarterly], no. 2, pp. 167-172. 